\title{
The Effect of Migration on Wages: Evidence from a Natural Experiment
}

\author{
By Dakshina G. De Silva, Robert P. McComb, Young-Kyu Moh, \\ ANita R. Schiller, AND ANDRES J. VARGAS ${ }^{\text {* }}$
}

The objective of this paper is to estimate the effect of immigration on workers' earnings. For this purpose, we take advantage of the natural experiment provided by the abrupt increase in the Houston-area population due to Hurricane Katrina. Unlike previous studies in this realm, and owing to the particular characteristics of this event, our model includes a measure of the demand for local goods and services.

David Card (2009) reviews the extensive literature on the effects of immigration on native populations' labor market outcomes. While there is little evidence that relative wage rates fall significantly as a direct consequence of immigration, none of these studies explicitly accounts for simultaneous shifts or exogenous shocks in demand. A geographically proximate catastrophic hurricane and resultant large scale in-migration, as observed in Houston at the end of 2005, clearly imply a proportionate increase in demand for certain imperfectly localized goods and services. In contrast, demand for production that is largely exported from the local economy and which trades in national or international

\footnotetext{
* De Silva: Department of Economics, PO Box 41014, Texas Tech University, Lubbock, TX 79409 (e-mail: dakshina.de-silva@ttu.edu); McComb: Department of Economics, PO Box 41014, Texas Tech University, Lubbock, TX 79409 (e-mail: robert.mccomb@ttu.edu); Moh: Department of Economics, PO Box 41014, Texas Tech University, Lubbock, TX 79409 (e-mail: young-kyu. moh@ttu.edu); Schiller: Wind Science and Engineering Research Center, PO Box 41023, Texas Tech University, Lubbock, TX 79409 (e-mail: anita.schiller@ttu.edu); Vargas: Department of Economics, PO Box 41014, Texas Tech University, Lubbock, TX 79409 (e-mail: andres.vargas@ttu.edu). We would like to thank Steve Trejo, Emek Basker, George Deltas, the 2009 International Industrial Organization Conference and 2009 Western Economic Association International Conference participants for helpful comments and suggestions. We also would like to thank the Texas Tech University Wind Science and Engineering Research Center for their ongoing research support. All errors and omissions remain our own.
}

markets will not be specifically affected by local or even regional demand shocks. There is thus a change in demand, attributable to the event, only for localized goods and services. This then implies an asymmetric response across the local industrial landscape in terms of the induced demand for labor services.

Based on Current Population Survey (CPS) data for November 2005 through August 2006, Molly F. McIntosh (2008) reports estimates that the evacuation resulted in a 3.1 percent increase in the population of the Houston metropolitan area. Most of the evacuees that remained in Houston one year later were younger and less educated than existing residents. Given the characteristics of the evacuees, their influx would have caused the supply of applicants for lower skilled jobs to increase proportionately more than for higher skilled jobs.

Katrina evacuees who remained outside the storm impacted area were provided with both financial and in-kind assistance as the circumstances in New Orleans, in particular, limited possibilities for their early return. Given financial support and a reduced urgency to enter the labor market, demand-side effects in labor markets may have preceded the supply-side effects due to the in-migration. Therefore, this study attempts to account for these demand-side influences by proxy. Actual statistical identification of the separate labor market supply and demand shifts is not possible due to data limitations. However, using sales tax data, we observe changes in the levels of final taxable sales. To the extent that initial effects in output markets are assumed to come from the demand side, the observed change in sales would reflect movement along the firms' supply curves and

${ }^{1}$ Jeffrey A. Groen and Anne E. Polivka (2008) report that 42.4 percent of nonreturnees received some form of governmental assistance. 
suggest a proportionate and exogenous change in demand for labor services.

We utilize a differences-in-difference-indifferences (DDD) methodology in which we compare the pre- and post-storm differences between average quarterly wages for workers in the low and high skill industries, by establishment, in the Houston and Dallas-Fort Worth Metropolitan Statistical Areas (MSAs). [ Using Dallas as a comparison group enables us to control for state specific and broader regional influences on the markets in the two subregions. We find evidence that the average quarterly wages of firms in low skill industries in Houston decreased by 0.7 percent relative to firms in high skill industries when compared to the same group of industries in Dallas before and after the hurricane. Our findings also suggest that the magnitude of this effect depends on the level of sales per firm and that failure to account for demand-side influences following the in-migration produces misleading results.

A theoretical reservation may be that real sales of localized goods and services are endogenous. Separating the endogenous from the exogenous component in the observed shift in demand is beyond the scope of this paper. While we cannot rule out endogenous effects, we can state confidently that a hurricane is exogenous and most evacuees to Houston had little choice in destination. We take the position that, at least in Houston in the aftermath of Katrina, there is a clear rationale for controlling for exogenous output market demand shocks due to the hurricane. Therefore, taking demand-side effects into account is essential when searching for the immigration's supply-side effects on wage rates and employment within this subset of industries.

\section{Data and Initial Observations}

We use two data sources. We obtained the Quarterly Census of Employment and Wages (QCEW) for Texas from the Texas Workforce Commission. The QCEW contains establishment level monthly employment and quarterly total wages for workers covered by unemployment insurance (UI). To proxy demand-side

\footnotetext{
${ }^{2}$ References to Houston and Dallas in this paper are intended to refer to the respective MSAs, not to the municipalities.
}

influences in labor markets, we use gross sales receipts of nontradable goods industries collected from the Texas Comptroller of Public Accounts. The unit of observation in the sales data is quarterly gross sales by industry at the four-digit NAICS for a given county.

The period of the DDD analysis is from the first quarter of 2004 through the fourth quarter of 2007. We exclude all tradable goods industries, industries that are not common to both Houston and Dallas, and self-employed workers. Our selection of nontradable goods industries is based on the work of Bradford J. Jensen and Lori G. Kletzer (2005). They estimate Gini coefficients of geographic concentration for each industry at the Metropolitan Statistical Area level. They categorize industries with a Gini coefficient below 0.1 as nontradable and industries with a Gini coefficient greater than or equal to 0.1 as tradable. The low skill sector comprises 27 industries with a total of 14,662 establishments and 487,894 workers in Houston and 17,028 establishments and 539,182 workers in Dallas. In the 55 industries that constitute the high skill sector, Houston has 16,057 establishments with 721,255 workers, and Dallas has 18,188 establishments with 774,740 workers.

Figures 1 and 2 present the density functions of the $\log$ of real average quarterly wages for low and high skill industries in Houston and Dallas before and after August 2005 ${ }^{\sqrt[3]{3}}$ We refer to the ratio of real average quarterly wages in the low skill industries relative to the high skill industries as relative average quarterly wages. Figure 1 shows that average quarterly wages for Houston-area low skill industries shifted left (declined) while high skill wages remained unchanged after Hurricane Katrina. It also suggests that the distributional shift for low skill industries can be observed for all ranges of wages. In contrast, Figure 2 shows that Dallas average quarterly wages for both low and high skill industries exhibited a slight rightward shift, indicating that relative wages have remained roughly unchanged since August 2005. Together, Figures 1 and 2 suggest that relative average quarterly wages declined in Houston but not in Dallas after Hurricane Katrina.

\footnotetext{
${ }^{3}$ Average quarterly wages represent the establishmentlevel total wage bill during the calendar quarter divided by the average monthly employment of the establishment during the quarter.
} 


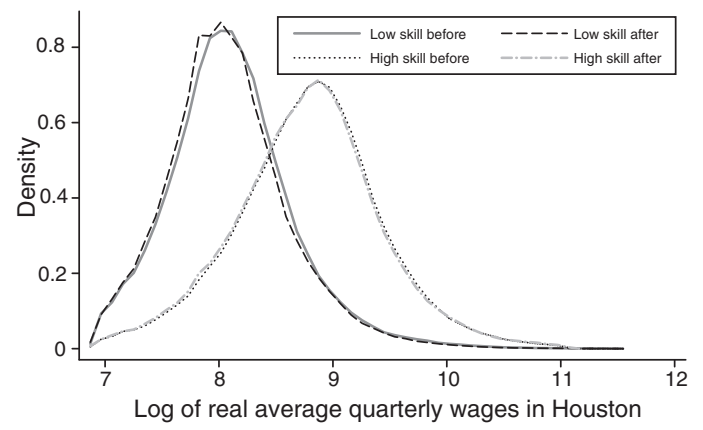

Figure 1. Average Quarterly Wage Distributions for HOUSTON MSA

\section{Empirical Model and Estimation Results}

The much greater in-migration of low skill workers into Houston should have led to a greater decline in relative average quarterly wages in Houston than in Dallas-Fort Worth. This effect might vary according to the demand for goods and services that the firm faces, as proxied by the level of sales per firm in the industry to which the firm belongs. The DDD estimation procedure can be summarized in the following reduced form wage equation:

$$
\begin{aligned}
(1) w_{i m t}= & \varphi_{i}+\alpha_{1}^{\prime} H_{m}+\alpha_{2}^{\prime} L_{i}+\alpha_{3}^{\prime}\left(H_{m} L_{i}\right) \\
& +\beta_{1}^{\prime} A+\beta_{2}^{\prime}\left(H_{m} A\right)+\beta_{3}^{\prime}\left(A L_{i}\right) \\
& +\beta_{4}^{\prime}\left(H_{m} A L_{i}\right)+\beta_{5}^{\prime} E_{i m t} \\
& +\beta_{6}^{\prime}\left(E_{i m t} L_{i}\right)+\beta_{7}^{\prime} S_{i m t} \\
& +\beta_{8}^{\prime}\left(S_{i m t} H_{m}\right)+\beta_{9}^{\prime}\left(S_{i m t} L_{i}\right) \\
& +\beta_{10}^{\prime}\left(S_{i m t} H_{m} L_{i}\right) \\
& +\beta_{11}^{\prime}\left(S_{i m t} A\right) \\
& +\beta_{12}^{\prime}\left(S_{i m t} H_{m} A\right) \\
& +\beta_{13}^{\prime}\left(S_{i m t} A L_{i}\right) \\
& +\beta_{14}^{\prime}\left(S_{i m t} H_{m} A L_{i}\right)+\varepsilon_{i m t} .
\end{aligned}
$$

where $w_{i m t}$ is the log of the real average quarterly wage of establishment $i$ in metropolitan area $m$ at time $t, \varphi_{i}$ controls for establishment level fixed effects, $H_{m}, A$ and $L_{i}$ are indicators for the

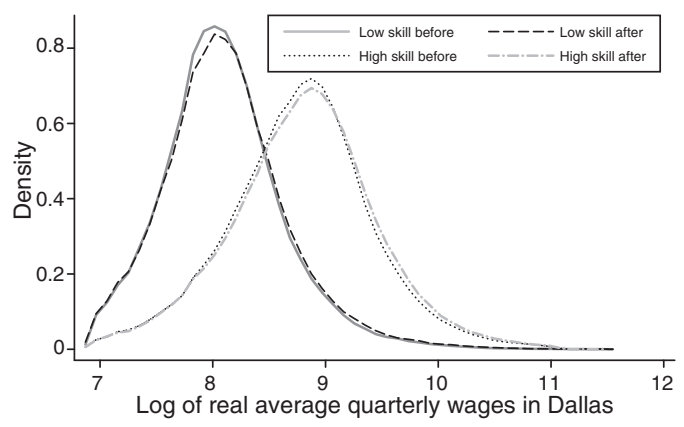

Figure 2. Average Quarterly Wage Distributions for DALLAS MSA

Houston MSA, the post-Katrina period, and the low skill sector, respectively. In addition, $E_{i m t}$ is the average employment of the establishment relative to the average employment of the industry in the county in a given quarter, and $S_{i m t}$ is the $\log$ of the industry sales per firm. Lastly, $\varepsilon_{i m t}$ is the random error term.

Note that we are interested in examining the change in establishment level average quarterly wages. We use a fixed effects estimation technique to examine the within establishment variation, controlling for establishment level unobservable heterogeneities. We estimate the fixed effects model using two different samples: (i) only firms in existence both before and after Hurricane Katrina, and (ii) all the firms in the sample regardless of their entry or exit date. In order to observe the effect of allowing for a differential impact of the in-migration according to the level of sales, we estimate the fixed effects regressions with and without the sales per firm interactions.

Table 1 reports results of the establishment level fixed-effects estimation of equation (1) using clustered standard errors at the establishment level. Columns 1a and 2a include interactions of sales per firm, whereas columns $1 b$ and $2 \mathrm{~b}$ do not. The $\beta_{4}$ coefficient compares the difference in average quarterly wages in the low skill firms in the Houston and Dallas MSA counties before and after the population influx generated by Hurricane Katrina to the same difference for the set of high skill firms. The $\beta_{14}$ allows for the previous effect to vary with the level of sales per firm.

In the specifications that include the sales per firm interactions, most of the coefficients 
Table 1-Regression Results for Log of Real Average Quarterly Wages

\begin{tabular}{|c|c|c|c|c|}
\hline & \multicolumn{2}{|c|}{ Before and after firms } & \multicolumn{2}{|c|}{ All firms } \\
\hline & $\begin{array}{l}\text { With sales } \\
\text { (1a) }\end{array}$ & $\begin{array}{c}\text { Without sales } \\
\text { (1b) }\end{array}$ & $\begin{array}{l}\text { With sales } \\
\text { (2a) }\end{array}$ & $\begin{array}{c}\text { Without sales } \\
\text { (2b) }\end{array}$ \\
\hline After Hurricane Katrina $\left(\beta_{1}\right)$ & $\begin{array}{r}-0.005 \\
(0.008)\end{array}$ & $\begin{array}{l}0.007 * * * \\
(0.002)\end{array}$ & $\begin{array}{r}-0.004 \\
(0.008)\end{array}$ & $\begin{array}{l}0.007 * * * \\
(0.002)\end{array}$ \\
\hline Houston $\times$ after Hurricane Katrina $\left(\beta_{2}\right)$ & $\begin{array}{l}0.080 * * * \\
(0.013)\end{array}$ & $\begin{array}{l}0.016^{* * * *} \\
(0.003)\end{array}$ & $\begin{array}{l}0.079 * * * \\
(0.013)\end{array}$ & $\begin{array}{l}0.016^{* * * *} \\
(0.003)\end{array}$ \\
\hline After Hurricane Katrina $\times$ low skill $\left(\beta_{3}\right)$ & $\begin{array}{c}0.017 \\
(0.018)\end{array}$ & $\begin{array}{l}-0.018 * * * \\
(0.002)\end{array}$ & $\begin{array}{c}0.018 \\
(0.018)\end{array}$ & $\begin{array}{l}-0.018 * * * \\
(0.002)\end{array}$ \\
\hline Houston $\times$ after Hurricane Katrina $\times$ low skill $\left(\beta_{4}\right)$ & $\begin{array}{l}-0.110^{* * * *} \\
(0.026)\end{array}$ & $\begin{array}{c}-0.005 \\
(0.004)\end{array}$ & $\begin{array}{l}-0.112 * * * \\
(0.026)\end{array}$ & $\begin{array}{c}-0.005 \\
(0.004)\end{array}$ \\
\hline Employment ratio $\left(\beta_{5}\right)$ & $\begin{array}{l}-0.630 * * * \\
(0.067)\end{array}$ & $\begin{array}{l}-0.627 * * * \\
(0.067)\end{array}$ & $\begin{array}{l}-0.667 * * * \\
(0.063)\end{array}$ & $\begin{array}{l}-0.663 * * * \\
(0.063)\end{array}$ \\
\hline Employment ratio $\times$ low skill $\left(\beta_{6}\right)$ & $\begin{array}{c}-0.398^{* * * *} \\
(0.116)\end{array}$ & $\begin{array}{l}-0.408^{* * * *} \\
(0.116)\end{array}$ & $\begin{array}{l}-0.420 * * * \\
(0.111)\end{array}$ & $\begin{array}{l}-0.429 * * * \\
(0.111)\end{array}$ \\
\hline Sales per firm $\left(\beta_{7}\right)$ & $\begin{array}{l}0.045^{* * *} \\
(0.002)\end{array}$ & $\begin{array}{l}0.032 * * * \\
(0.001)\end{array}$ & $\begin{array}{l}0.044 * * * \\
(0.002)\end{array}$ & $\begin{array}{l}0.032 * * * \\
(0.001)\end{array}$ \\
\hline Sales per firm $\times$ Houston $\left(\beta_{8}\right)$ & $\begin{array}{c}-0.015^{* * *} \\
(0.003)\end{array}$ & & $\begin{array}{c}-0.013 * * * \\
(0.002)\end{array}$ & \\
\hline Sales per firm $\times$ low skill $\left(\beta_{9}\right)$ & $\begin{array}{l}-0.018^{* * *} \\
(0.003)\end{array}$ & & $\begin{array}{l}-0.017 * * * \\
(0.003)\end{array}$ & \\
\hline Sales per firm $\times$ Houston $\times$ low skill $\left(\beta_{10}\right)$ & $\begin{array}{l}0.014 * * \\
(0.005)\end{array}$ & & $\begin{array}{l}0.013^{* *} \\
(0.005)\end{array}$ & \\
\hline Sales per firm $\times$ after Hurricane Katrina $\left(\beta_{11}\right)$ & $\begin{array}{c}0.001 \\
(0.001)\end{array}$ & & $\begin{array}{c}0.001 \\
(0.001)\end{array}$ & \\
\hline Sales per firm $\times$ Houston $\times$ after Hurricane Katrina $\left(\beta_{12}\right)$ & $\begin{array}{l}-0.005^{* * *} \\
(0.001)\end{array}$ & & $\begin{array}{c}-0.005^{* * *} \\
(0.001)\end{array}$ & \\
\hline Sales per firm $\times$ after Hurricane Katrina $\times$ low skill $\left(\beta_{13}\right)$ & $\begin{array}{c}-0.003 \\
(0.001)\end{array}$ & & $\begin{array}{c}-0.003 \\
(0.001)\end{array}$ & \\
\hline $\begin{array}{l}\text { Sales per firm } \times \text { Houston } \times \text { after Hurricane Katrina } \\
\quad \times \text { low skill }\left(\beta_{14}\right)\end{array}$ & $\begin{array}{l}0.009 * * * \\
(0.002)\end{array}$ & & $\begin{array}{l}0.009 * * * \\
(0.002)\end{array}$ & \\
\hline Observations & $1,051,812$ & $1,051,812$ & $1,254,407$ & $1,254,407$ \\
\hline Adjusted $R^{2}$ & 0.853 & 0.853 & 0.853 & 0.853 \\
\hline
\end{tabular}

Note: Robust clustered standard errors at the establishment level are in parentheses.

*** Significant at the 1 percent level.

**Significant at the 5 percent level.

are statistically significant at conventional levels. Only the coefficients for the dummies that control for the change in the average quarterly wages of high and low skill firms in Dallas after Hurricane Katrina $\left(\beta_{1,} \beta_{3}, \beta_{9}\right.$, and $\left.\beta_{13}\right)$ are statistically insignificant. It is important to note that there are no significant differences in the results between the regressions that include all the firms in the sample and those that include only firms in existence both before and after hurricane Katrina.
The net effect of the Katrina-induced migration on Houston area wages is given by $\beta_{4}+\beta_{14} \times S_{\text {imt }}$. Table 2 illustrates this effect at different points on the distribution of sales per firm. Evaluated at its average level, we find a statistically significant 0.7 percent drop in the average quarterly wages of low skill establishments in Houston relative to the change for the same group of industries in Dallas and relative to the corresponding change in the high skill industries. The effect is both negative and greater 
Table 2-Effect on Relative Average Quarterly Wages by Levels of Sales Per Firm

\begin{tabular}{|c|c|c|c|c|c|c|}
\hline \multirow{2}{*}{$\frac{\text { Percentile }}{10}$} & \multirow{2}{*}{$\begin{array}{c}\begin{array}{c}\text { Log sales } \\
\text { per firm }\end{array} \\
9.27\end{array}$} & \multirow{2}{*}{$\begin{array}{c}\begin{array}{c}\text { Effect } \\
\text { (percent) }\end{array} \\
-3.1\end{array}$} & \multirow{2}{*}{$\frac{\text { SE }}{0.007}$} & \multirow{2}{*}{$\frac{P>|t|}{0.00}$} & \multicolumn{2}{|c|}{$\begin{array}{c}95 \text { Percent } \\
\text { confidence interval }\end{array}$} \\
\hline & & & & & $-4.5 \%$ & $-1.7 \%$ \\
\hline 20 & 10.98 & -1.6 & 0.004 & 0.00 & $-2.5 \%$ & $-0.8 \%$ \\
\hline 30 & 11.90 & -0.9 & 0.004 & 0.02 & $-1.6 \%$ & $-0.1 \%$ \\
\hline Mean & 12.08 & -0.7 & 0.004 & 0.05 & $-1.4 \%$ & $0.0 \%$ \\
\hline 50 & 12.38 & -0.4 & 0.004 & 0.21 & $-1.2 \%$ & $0.3 \%$ \\
\hline 70 & 13.15 & 0.2 & 0.004 & 0.61 & $-0.6 \%$ & $1.0 \%$ \\
\hline 80 & 13.54 & 0.5 & 0.005 & 0.23 & $-0.3 \%$ & $1.4 \%$ \\
\hline 90 & 14.13 & 1.0 & 0.005 & 0.05 & $0.0 \%$ & $2.1 \%$ \\
\hline
\end{tabular}

in magnitude for levels of sales per firm below the median, statistically insignificant for levels of sales per firm between the median and the eightieth percentile, but positive and statistically significant for levels of sales per firm above the ninetieth percentile. The coefficient $\beta_{14}$ indicates that a ten percent increase in the level of sales per firm reduces the magnitude of the decline in relative average quarterly wages by 0.1 percentage points. Finally, the fact that the DDD coefficient $\beta_{4}$ becomes statistically insignificant if we fail to interact it with the sales per firm variable, as shown in columns $1 b$ and $2 b$, highlights the importance of including the proxy for demand for location specific goods and services.

Figure 1 illustrates that the distribution of average quarterly wages for low skill industries in Houston shifted left for all ranges of wages. This basic observation can be usefully analyzed using a quantile regression model. We restrict the estimation to three quantiles: $0.25,0.50$, and 0.75 . The analysis employs the specification described in equation (1) but with industry rather than establishment level effects. The results are similar to those obtained in the conditional-mean model.

Finally, to investigate whether Houston was already experiencing a downward trend in relative average quarterly wages around the evacuation period, either in absolute terms or relative to Dallas, we estimate the reduced form wage equation using only establishment level data from the pre-Hurricane Katrina time period. The model includes an overall trend term interacted with indicator variables for Houston and the low skill sector. The estimated trend terms point to a general decline in real wages for low skill industries but no change in real wages for high skill industries at the establishment level in both Houston and Dallas. However, the trends for both the high skill and low skill industries are not statistically different between the two regions. Hence, we conclude that prior to Hurricane Katrina, relative average quarterly wages in Houston were not trending downward compared to Dallas.

\section{Conclusions}

The objective of this paper was to estimate the effect of immigration on workers' earnings. Using a DDD methodology, we find evidence that, evaluated at the average sales per firm, the relative average quarterly wages in Houston decreased by 0.7 percent compared to the same group of industries in Dallas following the abrupt in-migration to Houston. Our results also indicate that a ten percent increase in the level of sales per firm diminishes the magnitude of the reduction in relative average quarterly wages by 0.1 percentage points. Given an inelastic demand for low skilled labor (cf. Daniel Hamermesh 1993), these estimates represent only a lower bound of the actual effect on hourly wages in the low skill nontradable goods industries. Lastly and importantly, the same DDD becomes statistically insignificant if we fail to include a proxy for demand-side effects.

\section{REFERENCES}

- Card, David. 2009. "Richard T. Ely Lecture: Immigration and Inequality." American Economic Review, 99(2): 1-21. 
Groen, Jeffrey A., and Anne E. Polivka. 2008. "Hurricane Katrina Evacuees: Who They Are, Where They Are, and How They Are Faring." Monthly Labor Review, 131(3): $32-51$.

Hamermesh, Daniel S. 1993. Labor Demand. Princeton, NJ: Princeton University Press.

Jensen, J. Bradford, and Lori G. Kletzer. 2005.

"Tradable Services: Understanding the Scope and Impact of Services Offshoring." In Brookings Trade Forum 2005: Offshoring WhiteCollar Work, ed. Lael Brainard and Susan M. Collins, 75-133. Washington, DC: Brookings Institution.

-McIntosh, Molly F. 2008. "Measuring the Labor Market Impacts of Hurricane Katrina Migration: Evidence from Houston, Texas." American Economic Review, 98(2): 54-57. 


\section{This article has been cited by:}

1. Dakshina G. De Silva, Robert P. McComb, Anita R. Schiller. 2013. Do production subsidies have a wage incidence in wind power?. Applied Economics 45:28, 3963-3972. [CrossRef]

2. Eduardo Rodriguez-Oreggia, Alejandro De La Fuente, Rodolfo De La Torre, Hector A. Moreno. 2013. Natural Disasters, Human Development and Poverty at the Municipal Level in Mexico. Journal of Development Studies 49:3, 442-455. [CrossRef]

3. Eduardo Rodríguez-Oreggia. 2013. Hurricanes and labor market outcomes: Evidence for Mexico. Global Environmental Change 23:1, 351-359. [CrossRef]

4. Dakshina G. De Silva, Robert P. McComb. 2012. Geographic concentration and high tech firm survival. Regional Science and Urban Economics 42:4, 691-701. [CrossRef]

5. Robert McComb, Young-Kyu Moh, Anita R. Schiller. 2010. Measuring long-run economic effects of natural hazard. Natural Hazards . [CrossRef] 